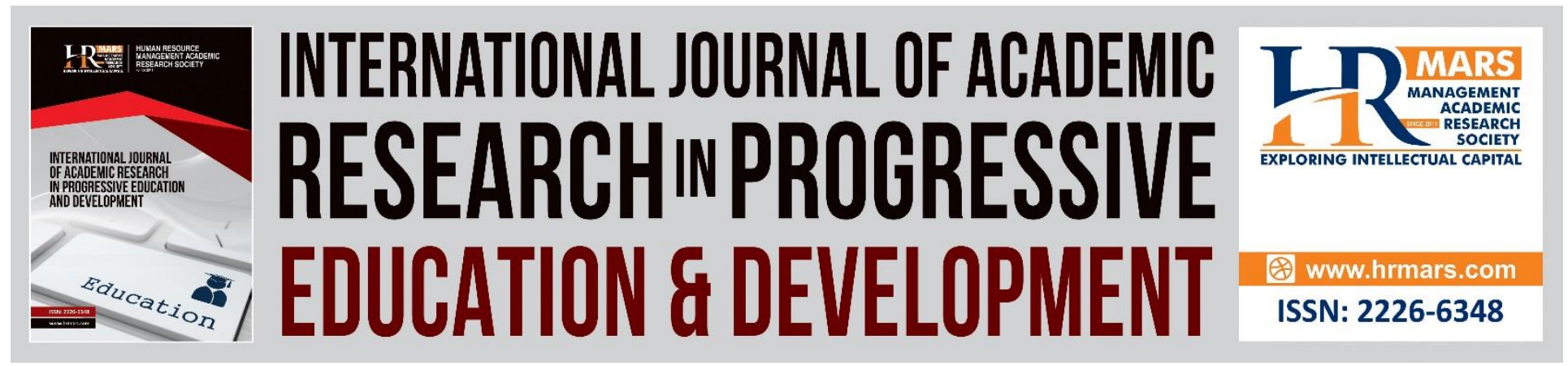

\title{
Teachers of North Kinta Schools' Level of Implementation Policy of Classroom Assessment
}

Puteri Rothiah Binti Megat Yahaya, Mazarul Hasan Bin Mohamad Hanapi \& Faridah Hanim Binti Yahaya

To Link this Article: http://dx.doi.org/10.6007/IJARPED/v9-i2/7517

DOI:10.6007/IJARPED/v9-i2/7517

Received: 18 April 2020, Revised: 23 May 2020, Accepted: 14 June 2020

Published Online: 28 June 2020

In-Text Citation: (Yahaya et al., 2020)

To Cite this Article: Yahaya, P. R. B. M., Hanapi, M. H. B. M., \& Yahaya, F. H. B. (2020). Teachers of North Kinta Schools' Level of Implementation Policy of Classroom Assessment. International Journal of Academic Research in Progressive Education and Development, 9(2), 534-543.

Copyright: (C) 2020 The Author(s)

Published by Human Resource Management Academic Research Society (www.hrmars.com)

This article is published under the Creative Commons Attribution (CC BY 4.0) license. Anyone may reproduce, distribute, translate and create derivative works of this article (for both commercial and non-commercial purposes), subject to full attribution to the original publication and authors. The full terms of this license may be seen

at: http://creativecommons.org/licences/by/4.0/legalcode

Vol. 9(2) 2020, Pg. 534 - 543

http://hrmars.com/index.php/pages/detail/IJARPED

JOURNAL HOMEPAGE

Full Terms \& Conditions of access and use can be found at http://hrmars.com/index.php/pages/detail/publication-ethics 


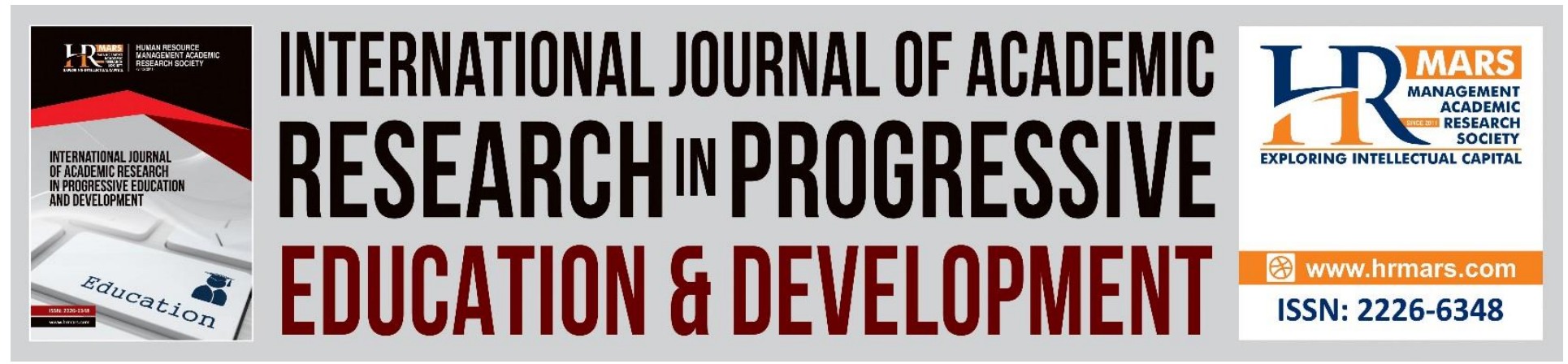

\title{
Teachers of North Kinta Schools' Level of Implementation Policy of Classroom Assessment
}

\author{
Puteri Rothiah Binti Megat Yahaya, Mazarul Hasan Bin Mohamad \\ Hanapi \& Faridah Hanim Binti Yahaya \\ Faculty of Human Development, Universiti Pendidikan Sultan Idris, 35900, Tanjong Malim, \\ Perak, Malaysia.
}

\begin{abstract}
The aim for this research is to identifying practice assessment among teachers in one of the schools in Kinta Utara. This research is a quantitative research with survey method by using a questionnaire. Hundreds of teachers from the school were picked randomly to participate in this research. All of them are teachers who have attended a full-time course by the Ministry and have been certificated as teachers. The min score value of each level for element value is analyzed by using the software Statistical Packages for The Social Sciences 23 (SPSS 23). The result of the research show that all element assessment is at a high level.
\end{abstract}

Keywords: Assessment, Classroom, Teaching, Learning, Attitude, Teacher.

\section{Introduction}

Assessment is one of the important aspects in evaluating student achievement. Thus, teachers have to take the initiative towards excelling country's education. Aim of good and perfect being with and able to appreciate qualities such as trust and obedient to God, knowledgeable, virtuous, responsible towards oneself, society, religion and country, to serve and contribute towards society and country and last but not least importantly having stable and concerted character.

Malaysian Education Development Plan (2013-2015) enables us to foresee various aspects. Eleven displacements produced which in all aimed at global level education. First displacement caters to us equal access towards international level quality education.

Research scope only focuses on teacher assessment policy in classroom for school where researcher conducts research. This research also sees policies conducted by teacher in executing assessment on students consisting alignment, trust in assessment, assessment types and form, management of assessment and how far the teachers in the school where the research conducted have creativity and innovation. Research yield and decision are limited to population samples involved and cannot be generalized to other population. 


\section{Research Objectives}

1. Identify teacher's level of alignment score before carrying out assessment.

2. Identify Trust in Assessment level of score practiced by teacher.

3. Identify Type and Form of Assessment Score built by teacher.

4. Identify Assessment Management level of score conducted by teacher in assessment.

5. Identify teacher's Creativity and Innovation level of score in preparing and implementing assessment.

\section{Literature Review}

Research by Ali and Jamaluddin (2007), indicates a fraction of teachers were less knowledgeable and skilled in developing assessment items. As a result, teachers were not able to formulate questions on their own (Lembaga Peperiksaan Malaysia, 2014) and formulate according to stated test specification table and required level of quality in planning assessment items. This phenomena causes teachers to fail to observe learning development, hence forth could not produce fair decision, weakens teaching plans and could not elicit real students' potentials.

According to Cheung et al (2001), most teachers felt that education system changes increased their workload. Teachers are aware of this assessment, making their schedules more compact. Not only teaching but also administering and curriculum work. Teachers need to assess and teach at the same time (Gan, 2012).

Teacher's level of readiness in carrying out school based assessment (SBOA), research by Abdul Khalil and Awang (2016) indicates teachers still lack training and basic skills and other material sources to use as references to carry out assessment. So, they could not make accurate assessment mainly in attaining assessment according to test specification table.

As a conclusion from the scenario, reports given to parents were inaccurate. Jaafar dan Rahman, (2008) stated such implication generate distrust and in surety among various counterparts towards quality assessment due to failure in attaining full accountable assessment (Talib \& Abd. Ghafar, 2009).

As teachers with visions to make international level education in 2020, surely can accept changes introduced by Ministry of Education. Teachers must change and do not ponder in the old notch. $21^{\text {st }}$ century learning indicates various learning kits or tools to teachers which can be applied in classrooms to head towards excellent achievement in assessment.

\section{Methodology}

This study was conducted at one of the schools in North Kinta district, Ipoh. The school was selected because it is a cluster of Excellence Clusters and has 106 teachers. Looking at the large number of teachers and having special remedial classes attracted researchers to know the level of implementation of classroom assessment practices in the school. A total of 100 teachers from 106 teachers were involved in this survey.

Research conducted was quantitative research to identify assessment policy among teachers. Exploratory method was carried out to receive feedback from respondents. After all the data received by the researcher, the data was analyzed using the help of 'Statistical Package for the Social Science' (SPSS) Version 23. 
This questionnaire consists of two main parts. The first part is the demography of the teacher whereby the researcher will discuss the gender, race, highest academic qualification, professional qualification, teaching experience and subjects or main areas of teaching for the period 2012 to 2017.

The second part of the research consist of five main sub parts based on teachers' alignment, trust in assessment, type and form of assessment, management of assessment and creativity and innovation. All the question items were answered as 5scores Likert scale (from 1=does not agree at all, $2=$ does not agree, $3=$ less agree, 4= agree and till 5=really agree).

\section{Finding and Result}

\section{Background of Respondent}

Research subject consist of 100 teachers from a school located in the district of North Kinta, Ipoh, Perak. Subject composition consist of $23(23 \%)$ male teachers and $77(77 \%)$ female teachers. Data shows female teacher populate teaching duty of this school.

Table 1. Distribution of Respondents According to Gender

\begin{tabular}{ccc}
\hline Gender & Frequency & Percentage \\
\hline Male & 23 & 23.0 \\
Female & 77 & 77.0 \\
\hline Total & 100 & 100.0 \\
\hline
\end{tabular}

According to Table 2, distribution of academic qualification aspect shows a total 60 people (60\%) as degree holders, 20 people (20\%) as diploma holders, 17 people (17\%) as SPM certificate holders, 2 people (2\%) as STPM certificate holders and 1 person (1\%) as master's holder. But none of the respondents are doctorate holders. Teachers with degrees dominate the academic qualification to adhere the government's intent to have all the primary and secondary school teachers to have at least a degree qualification. By providing degree programs for all teachers in 2006 , it was a move to uplift the teachers' standards by the government.

Table 2. Distribution of Respondents According to Academic Qualification

\begin{tabular}{ccc}
\hline Academic Qualification & Frequency & Percentage \\
\hline SPM & 17 & 17.0 \\
STPM & 2 & 2.0 \\
Diploma & 20 & 20.0 \\
Degree & 60 & 60.0 \\
Masters & 1 & 1.0 \\
\hline Total & 100 & 100.0 \\
\hline
\end{tabular}

According to Table 3, teaching experience aspect shows teachers who teach between 11 to 20 years dominate the school consisting of 56 persons (56\%). Teachers who teach between 21 to 30 years consist of 25 persons (25\%) and 6 persons (6\%) teach less than 10 years. This shows many of them are able in classroom assessment. 
INTERNATIONAL JOURNAL OF ACADEMIC RESEARCH IN PROGRESSIVE EDUCATION AND DEVELOPMENT

Vol. 9, No. 2, 2020, E-ISSN: $2226-6348$ @ 2020 HRMARS

Table 3. Distribution of Respondents According to Teaching Experience

\begin{tabular}{ccc}
\hline Teaching Experience & Frequency & Percentage \\
\hline $5-10$ Years & 16 & 16.0 \\
$11-20$ Years & 56 & 56.0 \\
$21-30$ Years & 25 & 25.0 \\
31 Years and Above & 3 & 3.0 \\
\hline Total & 100 & 100.0 \\
\hline
\end{tabular}

\section{Finding and Result}

There are five construct in questionnaire with a total of 41 sub item questions in section. Construct one for alignment, construct two for reliability in assessment, construct three for types and form of assessment, construct four for management of assessment and construct five for creativity and innovation. Each section of construct is analyzed using frequency scale table. Then, discussion is conducted according to table to answer research questionnaires stated.

To interpret research data using min score for each value of construct, researcher uses table 4 adaptations from view point of Wiersman (2000) and Rahimah (2006) which become the indicator for each average min score value.

Table 4. Categorization of Min Score according to research (Weirsma, 2000) and (Rahimah, 2006)

\begin{tabular}{cc}
\hline Categorization of Min Score & Evaluation Level \\
\hline $0.00-2.49$ & Low \\
$2.50-3.49$ & Medium \\
$3.50-5.00$ & High \\
\hline
\end{tabular}

\section{What is Alignment Level Score?}

Result from research conducted on 100 teachers in one of the schools in North Kinta District involving Classroom Assessment Policy regarding alignment section item which can be seen on Table 5 Frequency and percentage are as follow:

Table 5. Min Score Value for Items in Construct for Alignment Dimension

\begin{tabular}{|c|c|c|c|c|}
\hline Item & Statement of Item & Min & $\begin{array}{l}\text { Standard } \\
\text { Deviation }\end{array}$ & Interpretation \\
\hline 1 & $\begin{array}{l}\text { I plan assessment duty according to learning } \\
\text { outcomes }\end{array}$ & 4.03 & 0.66 & High \\
\hline 2 & I use feedback to make improvement in teaching & 3.93 & 0.67 & High \\
\hline 3 & $\begin{array}{l}\text { I develop assessment duty according to Duty } \\
\text { Specification Table }\end{array}$ & 3.89 & 0.63 & High \\
\hline 4 & $\begin{array}{l}\text { I develop test item according to Test Specification } \\
\text { Table }\end{array}$ & 3.76 & 0.75 & High \\
\hline 5 & $\begin{array}{l}\text { I believe alignment can increase confirmation of } \\
\text { assessment content }\end{array}$ & 3.84 & 0.73 & High \\
\hline & Overall & 3.89 & 0.69 & High \\
\hline
\end{tabular}


Vol. 9, No. 2, 2020, E-ISSN: $2226-6348$ @ 2020 HRMARS

Findings indicates min score for Alignment Construct are at high level with $\min =3.89$ and standard deviation=0.69. Thorough analysis indicates high min score in item 1 (I plan assessment duty according to learning outcomes) with $\mathrm{min}=4.03$ and standard deviation $=0.66$. While lowest $\min$ score indicated at item 4 (I develop test item according to Test Specification Table) with min=3.76 and standard deviation $=0.75$.

\section{What is Score level for Reliability in Assessment?}

Result from research conducted on 100 teachers involving Classroom Assessment Policy section reliability in assessment can be seen in Table 6. Frequency and percentage are stated as follow:

Table 6. Min Score Value for Items in Construct Reliability in Assessment

\begin{tabular}{|c|c|c|c|c|}
\hline Item & Statement of Item & Min & $\begin{array}{l}\text { Standard } \\
\text { Deviation }\end{array}$ & Interpretation \\
\hline KDP1 & $\begin{array}{l}\text { I believe assessment process can increase } \\
\text { pupils' learning process }\end{array}$ & 3.99 & 0.56 & High \\
\hline KDP2 & $\begin{array}{l}\text { believe assessment process must be } \\
\text { transparent }\end{array}$ & 4.00 & 0.75 & High \\
\hline KDP3 & $\begin{array}{l}\text { I believe pupils must be given the freedom to } \\
\text { decide assessment duties }\end{array}$ & 3.51 & 0.73 & High \\
\hline KDP4 & $\begin{array}{l}\text { I believe pupils must be given the freedom to } \\
\text { choose assessment duties }\end{array}$ & 3.75 & 0.75 & High \\
\hline KDP5 & I explain rubric markings to pupils & 3.58 & 0.73 & High \\
\hline KDP6 & I develop rubric markings with my pupils & 3.29 & 0.84 & High \\
\hline KDP7 & $\begin{array}{l}\text { I believe form of assessment must be according } \\
\text { to suitable learning theory }\end{array}$ & 3.85 & 0.59 & High \\
\hline \multirow[t]{2}{*}{ KDP8 } & $\begin{array}{l}\text { I believe assessment must be able to measure } \\
\text { different dimension of } 21^{\text {st }} \text { century learning. }\end{array}$ & 3.87 & 0.96 & High \\
\hline & Overall & 3.73 & 0.74 & High \\
\hline
\end{tabular}

Result of min score for construct reliability in assessment is at high level with $\min =3.73$ and standard deviation $=0.74$. Thorough analysis indicates high min score shown on item 2 (I believe assessment process must be transparent) with $\min =4.00$ and standard deviation $=0.75$. While lowest min score shown on item 6 (I develop rubric markings with my pupils) with $\mathrm{min}=3.29$ and standard deviation $=0.84$.

\section{What is Type and Form of Assessment Score Level?}

Result from research conducted on 100 teachers involving Classroom Assessment Policy that is form of assessment can be seen in table 7. Frequency and percentage are as stated below: 
INTERNATIONAL JOURNAL OF ACADEMIC RESEARCH IN PROGRESSIVE EDUCATION AND DEVELOPMENT

Vol. 9, No. 2, 2020, E-ISSN: 2226-6348 @ 2020 HRMARS

Table 7. Min Score Value for items in Type and Form of Assessment

\begin{tabular}{llccc}
\hline Item & \multicolumn{1}{c}{ Statement of Item } & Min & $\begin{array}{c}\text { Standard } \\
\text { Deviation }\end{array}$ & Interpretation \\
\hline JDBP1 & I use different forms of assessment & 4.00 & 0.66 & High \\
JDBP2 & I use authentic form of assessment & 3.62 & 0.74 & High \\
JDBP3 & I conduct formative assessment & 3.82 & 0.60 & High \\
JDBP4 & I conduct summative assessment & 3.78 & 0.59 & High \\
JDBP5 & I conduct online assessment & 3.30 & 0.85 & High \\
JDBP6 & I assess as criterion reference test & 3.52 & 0.91 & High \\
JDBP7 & I assess as criteria reference test & 3.60 & 0.88 & High \\
\hline & Overall & 3.66 & 0.74 & High \\
\hline
\end{tabular}

Result indicates min score for types and form of assessment construct is at high level with $\min =3.6$ and standard deviation $=0.74$. Through analysis indicates high min score shown on item 3 (I conduct formative assessment) $\mathrm{min}$ value $=3.82$ and standard deviation $=0.60$. While lowest min score shown on item 5 (I conduct online assessment) min value=3.33 and standard deviation $=0.85$.

\section{What is Assessment Management Level of Score?}

Result from research conduct on 100 teachers in a school in North Kinta district, Ipoh involving Classroom Assessment Policy for Assessment Management can be seen in Table 8. Frequency and percentage are stated below: 
INTERNATIONAL JOURNAL OF ACADEMIC RESEARCH IN PROGRESSIVE EDUCATION AND

DEVELOPMENT

Vol. 9, No. 2, 2020, E-ISSN: $2226-6348$ @ 2020 HRMARS

Table 8. Min score value for items in construct Assessment Management

\begin{tabular}{|c|c|c|c|c|}
\hline Item & Statement of Item & Min & $\begin{array}{l}\text { Standard } \\
\text { Deviation }\end{array}$ & Interpretation \\
\hline PP1 & $\begin{array}{l}\text { The weight of assessment depends on } \\
\text { requirement and importance of topic taught }\end{array}$ & 3.88 & 0.62 & High \\
\hline PP2 & $\begin{array}{l}\text { Formative assessment is more suitable to } \\
\text { measure outcome of learning for subjects taught } \\
\text { by me }\end{array}$ & 3.98 & 0.55 & High \\
\hline PP3 & $\begin{array}{l}\text { Summative assessment is more suitable to } \\
\text { measure outcome of learning for subjects taught } \\
\text { by me }\end{array}$ & 3.66 & 0.62 & High \\
\hline PP4 & $\begin{array}{l}\text { I recheck to weight age of assessment during } \\
\text { mid year }\end{array}$ & 3.79 & 0.72 & High \\
\hline PP5 & $\begin{array}{l}\text { I change again weight age of assessment } \\
\text { according to learning needs of pupils }\end{array}$ & 3.63 & 0.74 & High \\
\hline PP6 & I use analytical score method & 3.55 & 0.57 & High \\
\hline PP7 & I use holistic score method & 3.59 & 0.72 & High \\
\hline PP8 & Assessment report is done from time to time & 3.89 & 0.61 & High \\
\hline PP9 & $\begin{array}{l}\text { Assessment report is done at the end of } \\
\text { semester }\end{array}$ & 3.69 & 0.72 & High \\
\hline PP10 & Assessment report is done online & 3.47 & 0.88 & High \\
\hline PP11 & Assessment report is done in written form & 3.9 & 0.65 & High \\
\hline PP12 & $\begin{array}{l}\text { Feedback on assessment findings are given to } \\
\text { pupils in written form }\end{array}$ & 3.85 & 0.71 & High \\
\hline PP13 & $\begin{array}{l}\text { Feedback on assessment findings are given to } \\
\text { pupils in person }\end{array}$ & 3.71 & 0.82 & High \\
\hline PP14 & $\begin{array}{l}\text { Feedback on course work assessment is given to } \\
\text { pupils before examination }\end{array}$ & 3.47 & 0.83 & High \\
\hline PP15 & $\begin{array}{l}\text { Questions screening procedure can retain the } \\
\text { quality of the question developed }\end{array}$ & 3.68 & 0.83 & High \\
\hline & Overall & 3.71 & 0.70 & High \\
\hline
\end{tabular}

Result indicate min score for Assessment Management Construct is at a high level with min=3.71 and standard deviation $=0.70$. Thorough analysis indicates high min score indication on item 2 (Formative assessment is more suitable to measure outcome of learning for subjects taught by me) with $\min =3.98$ and standard deviation $=0.55$. While lowest min score indicated on item 14 (Feedback on course work assessment is given to pupils before examination) with min=3.47 and standard deviation $=0.83$.

\section{What is Creativity and Innovation Level of Score?}

Result from research conducted on 100 teachers in a school in Perak state involving Classroom Assessment Policy on creativity and innovation can be seen on Table 9. Frequency and percentage are stated as follow: 
Vol. 9, No. 2, 2020, E-ISSN: $2226-6348$ @ 2020 HRMARS

Table 9. Min score value for items in Creativity and Innovation Construct

\begin{tabular}{|c|c|c|c|c|}
\hline Item & Statement of Item & Min & $\begin{array}{l}\text { Standard } \\
\text { Deviation }\end{array}$ & Interpretation \\
\hline KD11 & $\begin{array}{l}\text { I instill Higher Order Thinking Skills (HOTS) } \\
\text { element in assigned question development }\end{array}$ & 3.82 & 0.67 & High \\
\hline KD12 & $\begin{array}{l}\text { I instill Higher Order Thinking Skills (HOTS) } \\
\text { element in test items development }\end{array}$ & 3.85 & 0.6 & High \\
\hline KD13 & $\begin{array}{l}\text { I stimulate pupils creativity through assessment } \\
\text { assignment given }\end{array}$ & 3.82 & 0.62 & High \\
\hline KD14 & $\begin{array}{l}\text { I encourage pupils to be innovative through } \\
\text { assessment assignment given }\end{array}$ & 3.71 & 0.83 & High \\
\hline \multirow[t]{2}{*}{ KD15 } & $\begin{array}{l}\text { I use suitable applications such as Kahoot, } \\
\text { Flickers, and others to carry out assessment of } \\
\text { pupils }\end{array}$ & 3.3 & 0.9 & High \\
\hline & Overall & 3.7 & 0.72 & High \\
\hline
\end{tabular}

Result indicates min score for Creativity and Innovation construct is at the high level with $\min =3.70$ and standard deviation $=0.72$. Thorough analysis indicates high min score on item 2 (I instill Higher Order Thinking Skills (HOTS) element in test items development) with min=3.85 and standard deviation=0.60. While lowest level min score shown on item 5 (I use suitable applications such as Kahoot, Flickers, and others to carry out assessment of pupils) with min=3.30 and standard deviation $=0.90$.

\section{Conclusion}

As a conclusion, it can be formulated that classroom assessment policy is an important tool to measure pupils' achievement especially to indicate whether an objective has been achieved or not. May the teachers become effective teachers who understand and use different assessment strategy to pupils and make sure the suitability before evaluation conducted. Teachers are told to find out education achievement of pupils from physical, mental and social with school community and the neighborhood.

As teachers use different assessment strategy and specialization of within you to increase level of knowledge and pupils' achievement from time to time but continuously.

\section{Acknowledgement}

Appreciation to all the parties involved in this research especially the headmaster and all the teachers who gave their full co-operation towards the research conducted.

\section{Corresponding Author}

Puteri Rothiah Binti Megat Yahaya

Faculty of Human Development, Universiti Pendidikan Sultan Idris, Malaysia

Email: puterirothiahskrj@yahoo.com 
INTERNATIONAL JOURNAL OF ACADEMIC RESEARCH IN PROGRESSIVE EDUCATION AND

DEVELOPMENT

Vol. 9, No. 2, 2020, E-ISSN: $2226-6348$ @ 2020 HRMARS

\section{References}

Abdul Khalil, F., \& Awang, M. I. (2016). Isu kesediaan guru dalam amalan melaksanakan Pentaksiran Berasaskan Sekolah. EDUCATUM-Journal of Social Science, 2(1), 1-7.

Ali, M. A. M., \& Jamaluddin, S. (2007). Amalan pentaksiran untuk pembelajaran di sekolah menengah. Jurnal Pendidikan, 27(1), 19-39.

Cheung, F. M., Leung, K., Zhang, J. X., Sun, H. F., Gan, Y. Q., Song, W. Z., \& Xie, D. (2001). Indigenous Chinese personality constructs: Is the five-factor model complete? Journal of cross-cultural psychology, 32(4), 407-433. doi: 10.1177/0022022101032004003

Gan, Z. (2012). Complexity measures, task type, and analytic evaluations of speaking proficiency in a school-based assessment context. Language Assessment Quarterly, 9(2), 133-151

Jaafar, K. B., \& Rahman, A. (2008). Pelaksanaan Pentaksiran kerja Kursus Kemahiran Hidup Bersepadu Sekolah Menengah Dalam Bandar Di Daerah Kuantan, Pahang. Universiti Teknologi Malaysia: Tesis Sarjana.

Kementerian Pendidikan Malaysia. (2012). Pelan Pembangunan Pendidikan Malaysia 2013 2015. Kuala Lumpur.

Lembaga Peperiksaan Malaysia. (2014). Laporan Kajian Pelaksanaan PBS: Dokumen Standard Prestasi. Kajian Berkaitan Pentaksiran Berasaskan Sekolah. Kuala Lumpur: Kementerian Pelajaran Malaysia.

Talib, R., \& Abd. Ghafar, M. N. (2009). Pembinaan dan Pengesahan Instrumen bagi Mengukur Tahap Literasi Pentaksiran Guru Sekolah Menengah di Malaysia. Universiti Teknologi Malaysia: Tesis PhD.

Wiersma, D. (2000). Laser physics: The smallest random laser. Nature, 406(6792), 132.

Wiersma, L. D. (2000). Risks and benefits of youth sport specialization: Perspectives and recommendations. Pediatric exercise science, 12(1), 13-22.

Wiersma, W. (2000). Research in Education: An Introduction. Boston: Allyn and Bacon. 